\title{
Development of the reproductive tract of immature gilts*
}

\author{
Anna Zmudzińska-Wojciech Kapelański
}

\author{
Jan and Jędrzej Śniadecki \\ University of Technology and Life Sciences \\ Faculty of Animal Breeding and Biology \\ Department of Pig Breeding \\ Mazowiecka St. 28, 85-084 Bydgoszcz \\ zmudzinska@utp.edu.pl
}

Keywords: Polish Landrace gilts, reproductive tract, uterus volume capacity, Pig Program Testing Station

SUMMARY

Mechanisms of regulation of litter size in pigs are complex and depend on many factors, including genetic regulation and also physiological and anatomical development of the reproductive tract in gilts. Improvement of growth rate in present breed pigs raises the question as to whether, with the development of the reproductive tract, sexual maturity would also be attained.

The aim of the study was to assess the morphometric traits of reproductive tracts taken from gilts slaughtered at $100 \mathrm{~kg}$ body weight, i. e., just when they may become actively sexual mature.

This study was concluded on 80 prepubertal gilts of the Polish Landrace (PL) breed tested at the Pig Program Testing Station. The animals were kept in individual pens with control feeding and standard management. They were slaughtered after attaining $100 \mathrm{~kg}$ body weight. Immediately after slaughter, the reproductive tract was removed and carefully assessed. The morphometric estimation of the reproductive tract involved the measurement of uterus weight with ligament, vagina-cervix length, uterine horns and oviducts length, ovaries weight, height and width. Uterus volume capacity was also determined, based on volumetric method of Kwaśnicki's (1951) with own modification.

All pigs were divided into three groups in respect to age at slaughter: A - below 160 days ( $\mathrm{n}=38), \mathrm{B}-$ from 160 to 180 days $(n=28)$ and $C$ - above 180 days of age $(n=14)$. The results were elaborated statistically computing the arithmetic means $(\mathrm{x})$ for every traits and standard deviations (s). One-way analysis of variance ANOVA was performed. The significance of differences between age groups was estimated using Duncan's test. Calculations were performed with STATISTICA 8PL Software.

Obtained results are presented in the tables below. The most pronounced differences in the development of the reproductive tract are dependent on the age of gilts concerning only the uterus weight $(\mathrm{P} \leq 0.01)$ and uterus vagina-cervix length $(\mathrm{P} \leq 0.05)$. Gilts at age 160-180 days attained the full stage of reproductive tract development. Differences between the compared age groups of gilts dealing with the other morphometric traits and ovary characteristics were statistically not significant.

*Academic study financed as research project by education funds between 2009-2012 
The results of morphometric estimation of reproductive tract in gilts dependent of age at slaughter

\begin{tabular}{|c|c|c|c|c|}
\hline \multirow{3}{*}{ Traits } & & \multicolumn{3}{|c|}{ Gilts group } \\
\hline & & A & B & $\mathrm{C}$ \\
\hline & & below 160 days & $160-180$ days & above 180 days \\
\hline Number, $\mathrm{n}$ & & 38 & 28 & 14 \\
\hline \multirow{2}{*}{ Body weight at slaughter, $\mathrm{kg}$} & $\mathrm{x}$ & 102.18 & 101.57 & 103.42 \\
\hline & $\mathrm{S}$ & 3.73 & 3.63 & 4.94 \\
\hline \multirow{2}{*}{ Age at slaughter, days } & $\mathrm{x}$ & $148.71^{\mathrm{A}}$ & $168.78^{\mathrm{B}}$ & $189.50^{\mathrm{C}}$ \\
\hline & $\mathrm{S}$ & 10.35 & 7.24 & 4.55 \\
\hline \multirow{2}{*}{ Uterus weight with ligament, $g$} & $\mathrm{x}$ & $142.10^{\mathrm{a}}$ & $215.21^{\mathrm{b}}$ & 183.64 \\
\hline & $\mathrm{S}$ & 56.85 & 149.10 & 90.91 \\
\hline \multirow{2}{*}{ Uterus vagina cervix length, $\mathrm{cm}$} & $\mathrm{x}$ & $11.57^{\mathrm{a}}$ & 12.50 & $13.35^{\mathrm{b}}$ \\
\hline & $\mathrm{S}$ & 1.82 & 3.14 & 2.67 \\
\hline \multirow{2}{*}{ Av. right and left horn length, $\mathrm{cm}$} & $\mathrm{x}$ & 47.31 & 55.03 & 52.91 \\
\hline & $\mathrm{S}$ & 8.76 & 21.66 & 14.91 \\
\hline \multirow{2}{*}{ Uterus volume capacity, $\mathrm{cm}^{3}$} & $\mathrm{x}$ & 141.49 & 158.89 & 171.28 \\
\hline & $\mathrm{S}$ & 54.00 & 77.64 & 73.37 \\
\hline \multirow{2}{*}{$\begin{array}{l}\text { Av. right and left oviducts length, } \\
\qquad \mathrm{cm}\end{array}$} & $\mathrm{x}$ & 20.08 & 21.07 & 20.14 \\
\hline & $S$ & 2.91 & 4.48 & 2.94 \\
\hline \multirow{2}{*}{$\begin{array}{l}\text { Av. right and left oviducts } \\
\text { diameter, mm }\end{array}$} & $\mathrm{x}$ & 2.55 & 2.43 & 2.56 \\
\hline & $\mathrm{S}$ & 0.75 & 0.73 & 0.25 \\
\hline \multirow{2}{*}{ Number of teats } & $\mathrm{x}$ & 14.55 & 14.57 & 14.42 \\
\hline & $\mathrm{S}$ & 0.92 & 1.23 & 0.85 \\
\hline
\end{tabular}

The results of ovaries estimation in gilts dependent of age at slaughter

\begin{tabular}{|c|c|c|c|c|}
\hline \multirow{3}{*}{ Traits } & & \multicolumn{3}{|c|}{ Gilts group } \\
\hline & & A & $\mathrm{B}$ & $\mathrm{C}$ \\
\hline & & below 160 days & $160-180$ days & above 180 days \\
\hline \multirow{2}{*}{ Av. right and left ovary weight, $g$} & $\mathrm{x}$ & 3.75 & 3.92 & 4.00 \\
\hline & $\mathrm{s}$ & 1.06 & 1.76 & 2.64 \\
\hline \multirow{2}{*}{ Av. right and left ovary length, $\mathrm{mm}$} & $\mathrm{x}$ & 25.65 & 25.94 & 25.87 \\
\hline & $\mathrm{s}$ & 2.47 & 3.96 & 4.17 \\
\hline \multirow{2}{*}{ Av. right and left ovary height, $\mathrm{mm}$} & $\mathrm{x}$ & 12.33 & 12.13 & 12.49 \\
\hline & $\mathrm{s}$ & 2.00 & 2.76 & 2.67 \\
\hline \multirow{2}{*}{ Av. right and left ovary width, mm } & $\mathrm{x}$ & 18.55 & 18.77 & 18.40 \\
\hline & $\mathrm{s}$ & 2.66 & 3.16 & 3.15 \\
\hline \multirow{2}{*}{$\begin{array}{l}\text { Av. right and left ovary volume, } \\
\qquad \mathrm{cm}^{3}\end{array}$} & $\mathrm{x}$ & 2.79 & 2.98 & 3.07 \\
\hline & $\mathrm{s}$ & 1.13 & 1.21 & 2.47 \\
\hline
\end{tabular}

\section{REFERENCES}

Kwaśnicki A. V., (1951): Fizjotogia piszczewarenijau swiniej. Sielchozjiat, Moskwa 